[41]高分子濃厚溶液 の物 性 論

第 7 報 硝酸繊維素アセトン溶液の熱伝導率

(1958 年 8 月 18 日受理)

竹中治夫* 荻野孝也*

要 旨 硝酸織維素ーアセトン溶液の全潭度筑囲にわたって平均温度 $25^{\circ} \mathrm{C}$ で熱伝導率を測定した。改 良した比較測定法を用いたが，特に接触热抵抗あるいは厚さ測定による呮差が入らないようくふうした。硝酸

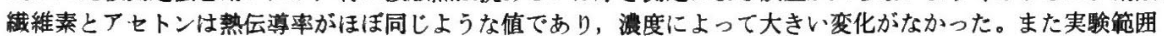
内では重合度依存性も認められない。

\section{1. 緒}

論

高分子溶液の熱层導率は化学工学上の基礎データとし て重要である。また物性値としても興味ある值である。 すなわち高分子鎖が無秩序な方向をもっていると考えら れる高分子溶液における熱层導は溶媒に上る熱伝導, 高 分子鎖間扔よび高分子鎖に沿う高分子内の熱伝導の重 なった現象と考えられる。したがって高分子溶液の熱伝 導率を測定し，それぞれの伝導機構の寄与の大小を推定 することは興味樑い問題である。そして溶液構造推定の 手がかりとすることもできよう。

熱伝導率の測定法は多数市るが，高分子物質，とくに 溶液に関して上のような解析にたえるに十分な測定例は 非常に数が少ない。われわれは誤差 $1 \%$ 以内で熱伝導率 を測定するために，特に接触熱抵抗，厚さ測定による誤

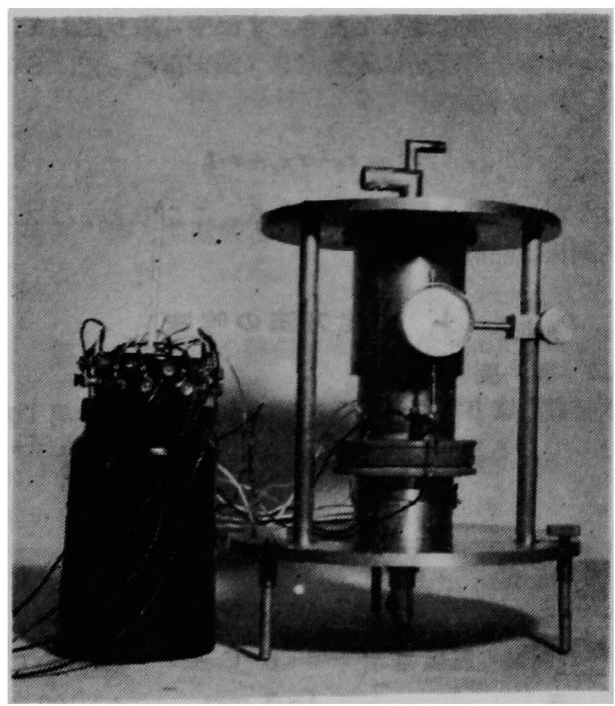

第 1 図測定装置

* 富士写真フィルム株式会社研究所(神奈川県足柄上郡南足柄 町中沼 210
差を除去した測定装置を製作し，硝酸繊維素ーアセトン溶 液について測定した。

\section{2. 測 定装置}

比較測定法を改良した。第 1 図にその外観写真, 第 2 図に原理的構造を示した。A, B は上下の恒温部であって それぞれ別に $\pm 5 / 1000^{\circ} \mathrm{C}$ の精度の恒温水槽から水を循 環する。Aにはガラス板 $\mathrm{G}$ をはり付け熱流計とする。C

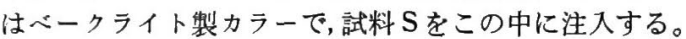
温度計は $0.1 \mathrm{~mm} \phi$ の銅ーコンスタンタン熱電対を 2 対 ずつ, $\mathrm{G} の$ 上下面およびBの上面に, 接点が断面(円)の中 心にくるよらそれぞれの面に約 $0.5 \mathrm{~mm}$ の溝を掘ってア ラルダイトで絶縁固定した。その上に保護用の研摩した ステンレス鋼板を, 同じくアラルダイトで接着, 焼付硬 化した。Dは $1 / 100 \mathrm{~mm}$ 目盛のダイヤルゲージで $\mathrm{A} の$

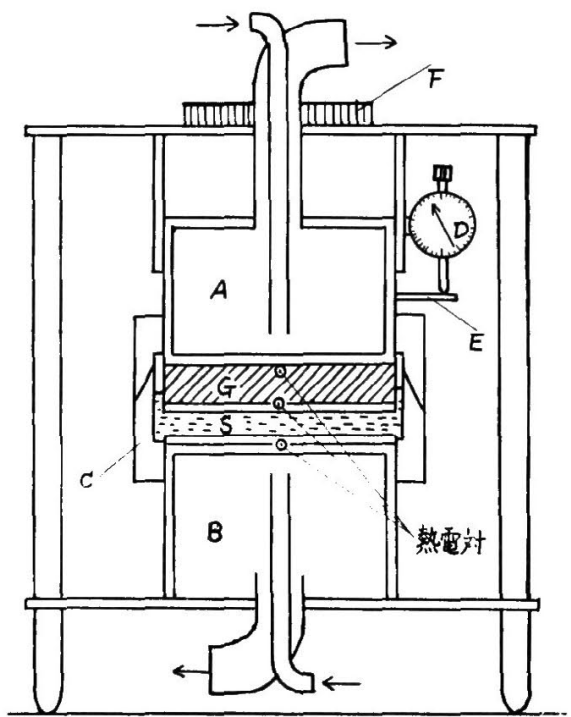

第 2 図装置の棈造 
卜筒に固定され，その測定針は内筒の突起 $\mathrm{E}$ に載せる。 ‘は円筒を上下するためのスクリューである。 装置の設計にあたり考虑した点は次の諸点である。

\section{1 熱流計, 試料の直径および厘さ}

比較法の場合, 熱流計と試料との熱抵抗が等しいとき, 灵も精度が良いので熱流計として用いたガラス板の厚さ よ次のようにして決めた。測定は試料の厚さ1〜3 mm ご行なうこととしたので，両者の熱抵抗(厚さ/熱伝導率) 卓等しくするためのガラス板の厚さは，ガラスおよび試 斗たとえば，硝酸纎維素の熱伝導率がそれぞれ約 $1.5 \times$ $0^{-3}, 0.4 \times 10^{-3} \mathrm{cal} / \mathrm{cm} \cdot \mathrm{sec}^{\circ} \mathrm{C}$ であるから

$$
\begin{aligned}
d_{G} & =0.2 \times 1.5 \times 10^{-3} / 0.4 \times 10^{-3} \\
& =0.7(\mathrm{~cm})
\end{aligned}
$$

上なる。以上は粗い計算の結果であるが,ここでは一応 i $\mathrm{mm}$ とした。

また熱流計と試料の厚さの和が，值径の 1/10 以下で られば，周辺からの冷却による誤差は $1 \%$ 以下上なるこ 上が知られている”。したがって式料の直径は $80 \mathrm{~mm}$ 上 した。

\section{2 保櫵用ステンレス龬板の厚さ}

2 枚の熱抵抗が試料の熱抵抗の $1 \%$ 以下となるように した。すなわち淕料の熱抵抗は $0.3 / 0.4 \times 10^{-8}$ で，ステ ンレス銿(18-8 ニッケルクローム鋼)の熱伝導率が約 70 $\times 10^{-3} \mathrm{cal} / \mathrm{cm} \cdot \mathrm{sec}^{\circ} \mathrm{C}$ であるから, その厚さ $d_{s}$ (1 枚)は

$$
\begin{aligned}
d_{s} & =70 \times 10^{-8} \times 0.01 \times 0.3 / 0.4 \times 10^{-3} \times 2 \\
& =0.245(\mathrm{~cm})
\end{aligned}
$$

以下であれば良い。ここでは 1 枚の厚さを $1 \mathrm{~mm}$ とし =0

\section{3 温度制御}

一定温度差，一定熱流の条件による測定を行なうため， 甬常の方法のような発熱量制御とせずに A， B とも温度 制御とした。またこうすることによって定常状態に達す るまでの時間が非常に短縮でき数分間で十分である。

\section{4 その他}

試料内の対流を防ぐためにAを高温，Bを低温よする ことは通常のとおりである。また溶媒の蒸発を防止する ために，カラーCは気密にすり合わせた。

\section{3. 測 定 方 法}

\section{1 温度の測定}

熱電対の起電力を植流電位差計で測定した。なおこ つとき用いたカドミウム標準電池も， $\pm 5 / 1000^{\circ} \mathrm{C}$ の精 哲の画温水槽内に入れ, 温度による起電力の变動を除い た。室内放置で約 $5 \times 10^{-4} \mathrm{~V}$ の変動を示したが，恒温 水槽内に入れることによって約 $1 \times 10^{-4} \mathrm{~V}$ となり，温度 則定の実験誤美以内となしえた。

\section{2 厚さの測定}

試料を注入したときと，試料を入れずに密着させたと きのダイヤルゲージの語みの差を試料の厚さとした。

\section{3 熱抵抗の測定}

電流との相似性を利用して，熱流計 Gの両端の温度が $T_{1}, T_{2}$, 試料の下端の温度が $T_{3}$ であるとき, 熱流計お よび試料を流れる熱流は等しいから, それぞれの熱抵抗 を $r_{G}, r_{s}$ とすれば

$$
\left(T_{1}-T_{2}\right) / r_{G}=\left(T_{2}-T_{8}\right) /\left(r_{0}+r_{s}\right)
$$

となる。ここで $r_{0}$ は接触熱抵抗および保護板の熱抵抗 を含む定数である。オーム則を適用すれば， $r_{s}=r \cdot t$ で 表わされるから，(1)式を書き直すと

$$
R=k\left(T_{2}-T_{3}\right) /\left(T_{1}-T_{2}\right)=r_{0}+r \cdot t
$$

となる。ここで $r$ は試料の比熱抵抗で熱伝導率の逆数に 比例する量, $t$ は厚さである。

\section{4 熱伝晜率の計算}

(2) 式に基き熱流一定の条件で $\left(T_{2}-T_{3}\right) /\left(T_{1}-T_{2}\right)$ を 測定し $R / k \sim t$ の関係を求め, その直線の勾配から，標 準物澌との比を用いて熱伝導率を計算する。こうして接 触熱抵抗および厚さの測定による誤差 (0 点の不明確さ) は $r_{0}$ の中に入ってしまい, 熱伝導率はこれらと独立に 測定できた。

液状のものは上のように測定できるが，高濃度のゲル 状のものは次のようにして測定した。平型の秤量びん中 に研摩したステンレス銚板を入れ，これを水平に保持し て濃度既知の溶液を流し込み，フタをして徐々に乾燥す る。所望の濃度に達したとき, すばやく取り出して, ス テンレス鋼板の下面に流動パラフィンを塗って， $\mathrm{S} に 入$ れた。 $R$ れ 直線は

$$
R=r_{0}+r_{F e}+r \cdot t
$$

よなるが，同じように取り扱える。ここで $r_{F e}$ はステン レス鋼板の熱抵抗である。

\section{4. 測定方法の吟味}

\section{1 精 度}

本装膡により得られると推定される精度は, 第 1 表の 上おりである。

\section{$\mathrm{A}$ 部の温度 \\ B "}

試料の両端の温度差 草さ

したがって比熱抵抗，すなわち熱伝導率も誤差 $1 \%$ 以 内で計算できる。
第

\begin{tabular}{c|l}
$1 \quad$ 衰 \\
\hline 約 $\quad \begin{array}{c}30^{\circ} \mathrm{C} \\
20^{\circ} \mathrm{C}\end{array}$ & $\pm 1 / 100^{\circ} \mathrm{C}$ \\
$5 \sim 6{ }^{\circ} \mathrm{C}$ & $\pm 1 / 100^{\circ} \mathrm{C}$ \\
$1 \sim 3 \mathrm{~mm}$ & $\pm 1 / 100^{\circ} \mathrm{C}$ \\
$1 \sim 3 \mathrm{~mm}$
\end{tabular}




\section{2 装置の較正}

熱伝導率既知の液体, すなわち水, グリセりン水溶液, $\mathrm{m}$-キシロールについて $R / k \sim t$ の関係を測定した。その 結果は第 3 図,またこれから得られた比熱抵抗と熟伝導 率の逆数 (文献值) との関係は第 4 図のとおりであって,

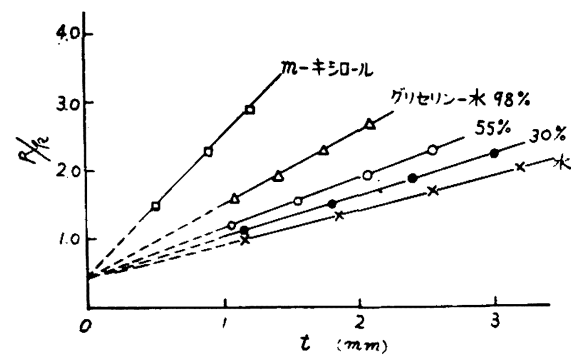

第 3 図液体の $R / k \sim t$ 直線

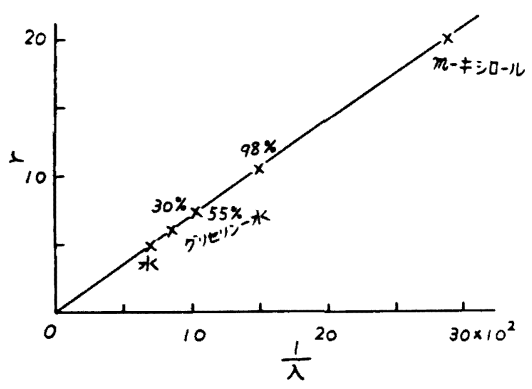

第 4 図 比熱抵抗 (実測値) と 熱伝導率の逆数 (文献値)

本測定方法が正しいことを示している。なお測定した熱 伝導率の值と文献值との比較は第 2 表のとおりであっ て,よく一致している。

第 2 表 液体の熱伝導率 $\left(\times 10^{-3} \mathrm{cal} / \mathrm{cm} \cdot \mathrm{sec}^{\circ} \mathrm{C}\right)$

\begin{tabular}{|c|c|c|c|c|}
\hline & & $\begin{array}{l}\text { 奏測值 } \\
\left(25^{\circ} \mathrm{C}\right)\end{array}$ & 文献 值 & 文献 \\
\hline 水 & & 1.43 & $1.43\left(25^{\circ} \mathrm{C}\right)$ & 2) \\
\hline グリセリン水溶液 & $30 \%$ & 1.16 & $1.16(")$ & 2) \\
\hline " & $55 \%$ & 0.972 & $0.96(")$ & 2) \\
\hline " & $90 \%$ & 0.666 & $0.67(")$ & 2) \\
\hline $\mathrm{m}$-キシロール & & 0.368 & $0.370\left(21^{\circ} \mathrm{C}\right)$ & 3) \\
\hline
\end{tabular}

ゲル状の場合には，ステンレス鎆板を入れることに よって接触熱抵抗にバラッキを生し， $R / k \sim t$ 関係の一例 は第 5 図のような結果であり，精度が落ちた。

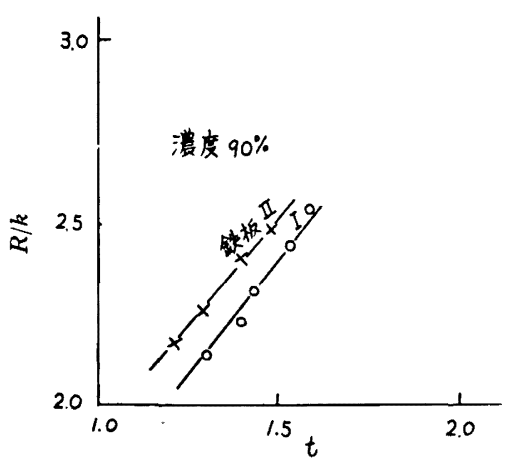

第 5 图 ゲル状試料の $R \sim t$ 值線

5. 測 定結果

用いた硝酸繊維素の性質を第 3 表に示すか。得られた 結果を第 6 図に示した。

高濃度側においては試料はゲル状であるので，さきに 述へた理由により結果はバラッキを示している。

a) 濃度による大きい変化はない。これは硝酸繊維 素, アセトンのいずれも熱伝導がほぼ同程度であるので 当然のように思われる。

b) 重合度依存性は認めら九ない。もし高分子鎖に沿 う熟伝導率の奇与が大きければ，重合度依存性が表われ ると思われる。しかし重合度依存性がないといっても， ただちに分子内伝導が小さいと考えることは a) の事実 を考虑すると妥当ではない。今後の問題として残され る。

\begin{tabular}{|c|c|c|c|}
\hline \multicolumn{3}{|c|}{ 第 3 表 試 } & \multirow{2}{*}{$\begin{array}{l}\text { 料 } \\
\text { 単量体の平均分子量 }\end{array}$} \\
\hline 試料 & 平均重合度 & 硝化度 & \\
\hline A & 164 & $11.88 \%$ & 262 \\
\hline B & 108 & $11.50 \%$ & 257 \\
\hline $\mathrm{C}$ & 56 & $11.65 \%$ & 259 \\
\hline
\end{tabular}

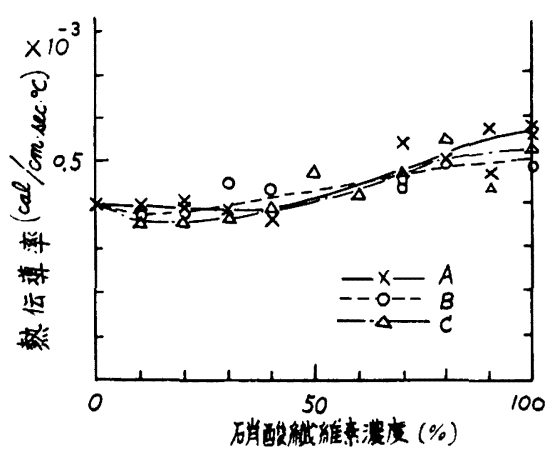

第 6 図 硝酸纎維素アセトン溶液の熱伝導率 
付 記：本研究は日本化学会第 10 年会で報告した。発 表のご許可をいただいた当社常務 藤沢信博士および研究所長 福田神郎氏に感謝の意を表するとともに測定に当った梅原喜 美子娘に感謝する。
文

献

1) 抜山四郎：熱伝導率測定法, 74（共立出版）

2) O.K. Bates: Ind. Eng. Chem., 28, 494 (1936)

3) Landolt und Börnstein Tablen

4) 竹中治夫：日化誌, 73, $510(1952)$

\title{
Chemical Physics of Concentrated Highpolymer Solution
}

VII. Thermal Conductivity of Nitrocellulose in Aceton Solution

\section{By Haruo Takenaka* and Takaya Ogino*}

\begin{abstract}
Thermal conductivity of nitrocellulose in acetone solution was measured in the whole range of concentrations at $25^{\circ} \mathrm{C}$. The method of measurement obtainable relative values of the conductivity was improved, special caution being paid on eliminating possible errors in the thermal resistance of the glass plate (as a standard) in contact with the sample solution and in the measurement of the thickness of the sample solution. Thermal conductvity of nitrocellulose is nearly equal to that of acetone, and its change with concentration and with the degree of polymerization was not obserbed.
\end{abstract}

* Research Laboratory, Fuji Photo Film Co., Ltd. (Minamiashigara-machi, Ashigarakami-gun, Kanagawa) 